\title{
我々の経験した神経病性関節症について
}

（特に膝関節の X 線像検討）

$\begin{array}{cccc}\text { 熊本大学整形外科 (主任 : 玉井達二教授) } \\ \text { 北 } & \text { 川 } & \text { 敏 } & \text { 夫 } \\ \text { 星 } & \text { 子 } & & \text { 亘 } \\ \text { 德 } & \text { 永 } & \text { 温 } & \text { 正 } \\ \text { 松 } & \text { 井 } & \text { 美 } & \text { 房 } \\ \text { 市 } & \text { 原 } & \text { 正 } & \text { 森 }\end{array}$

牛梁市立病院

松岡満

水俣市立病院

沼田亭

八代綜合病院

近藤 正 雄

\section{A Report of Fifteen Cases of Neurogenic Arthrosis}

(Some Roentgenographic Observations with Reference to Knee Joint)

By

T. Kitagawa, W. Hoshiko, A. Tokunaga,

Y. Matsui \& M. Ichihara

Department of Orthopedic Surgery,Kumamoto

University, Medical School

\section{Matsuoka}

Ushibuka Municipal Hospital

T. Numata

Minamata Municipal Hospital

M. Kondo

Yatsushiro General Hospital

Recently fifteen cases, twenty-two joints, of neurogenic arthrosis have been experienced. Eighty per cent of them were older than fifty years of age, and the youngest was twelve years old boy. Five patients were male and ten were female. Six patients complained of mild or moderate pain in affected joints, but nine had no pain.

Abnormal findings in the roentgenogram were observed in eleven knee joints (50\%), three ankle joints, two lumbosacral joints, two hip joints, two shoulder joints and two elbow joints.

Etiologically eleven cases (73.3\%) were caused by tabes dorsalis, and the others were by syringomyelia, poliomyelitis, peripheral neuritis and unknown.

In roentgenographic findings of the knee joints, there were noted lateral subluxation of tibial articular surface, periosteal thickness and marked bony changes, which were erosion or multiplication, at medial articular border of tibia and lateral articular border of femur in all 
cases.

Analyzing dynamic actions in neurogenic arthrosis of knee joints on the bases of these findings, we assumed that erosion and multiplication of the bones were easily occurred at medial tibial condyle and lateral femoral condyle.

\section{緒}

\section{言}

特異な X線像を呈する神経病性関節症に関しての報 告は, 1831年の Mitzer に始まり, 1868 年には Cha$\operatorname{rcot}$ が, 脳脊骾の障害, 特に脊䯣病に関係あるむの として, 詳細に報告し， Charcot Joint と命名され た、その後，今日まで数多くの報告がある，その原因 疾患として, 今日では, 脊能病や脊葡空洞症を始めと して，末梢神経炎にいたるまで，巾広い神経疾患が考 えられている. しかし，その直接原因に関しては， Charcot らの栄養神経障害説之, Volkmann らの外 㑺説などがあるが，未だ判然とした解答はない，従つ て, その悲断は, 臨床症状, 特に神経症状の有無之, 特異なX線像に頼る外はない。 なかでも, そのX線像 は，最む有力な彭断の助けとなる．発生部位に関して は，どの報告を見ても膝関節沉庄倒的に多く，本邦の 報告例に执いても約半数を占めている.

我々は, 最近, 15症例, 22関節の神経病性関節症を 経験したので, その概装を報告すると共に, 特に頻度 の多い滕関節について，X線像を中心に検討を加え， X線晾断の助けとしたいと考えたので，その点にもふ れてみたい.

\section{症例}

我々の経験した 15 例のうち, 年令分布では, 症例 (14) の12才を除き全て 38 才以上で，なかであ12例, 80\%か 50才以上であつた. 性別では, 男性 5 名, 女性 10名で女性に多く, 主派では, 脊椎および股関節を除 き, ほとんど全例に関節腫脹を認めた. 関節痛は, 軽 度ないし, 中等度のむのを 6 例に認め, 9 例には疼痛 を認めず，激痛は 1 例も認めなかつた。 骨関節変形部 位は，溙関節が 11 で $50 \%$ 占め, 足関節が 3 , 腰仙 椎, 股関節, 屃関節, 肘関節がそれぞれ 2 づつであつ た. また, 全症例に何らかの神経症状を認め, 梅毒反 応以外の血液その他の検査所見では, 症例 (3) の軽 度の血糖值の上昇と, 症例 (12) に, Eosinophilie 認めた外は, 著変を認めなかつた. 想定或いは確定さ

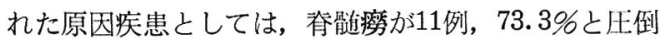
的に多く, その他脊骾空洞症と思われるもの1例, 末
梢神経炎 1 例, ポリオ 1 例, 不明 1 例であつた. 治療 法は，症例 (2) および (4) に圧迫関節㾪着術を試 み, 骨癒合に成功し, その他は, 補装具による治療を 行なつたが詳細に関しては，今回は省略する.

\section{膝関節 $\mathbf{X}$ 線 像}

特に膝関節のX線像をみると，症例 (1) では, 脛 骨の外側への移動之, 大腿骨外顆の骨破壊および大腿 骨脛骨の骨膜肥厚像を認めた。症例 (2) では, 脛骨 骨端部の著明な骨破壊と脛骨の外側への移動を認め た. 症例（3）では, 左は, 脛骨内顆部の破壊および 骨増殖を認め, 脛骨の外側への移動を認めると共に, 骨

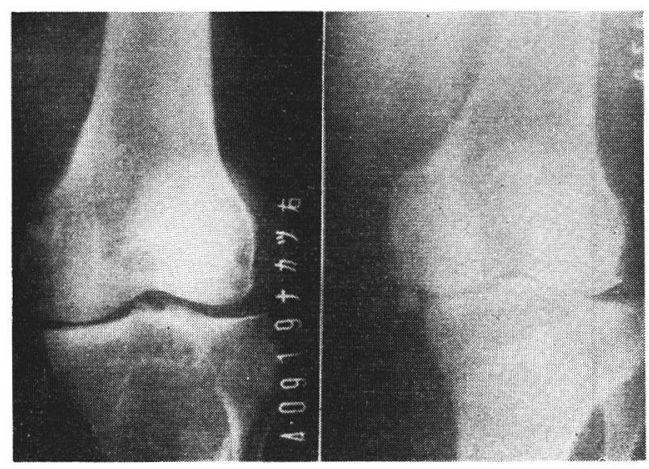

a

b

図 1 症例 3 右滕関節

a 昭40年 9 月

脛骨の外側移動を軽度に認め脛骨内顆及び大 腿骨外顆に軽度の骨变化を認める。

b 炤 41 年 6 月（9ケ月後） aの所見が更に著明となる。

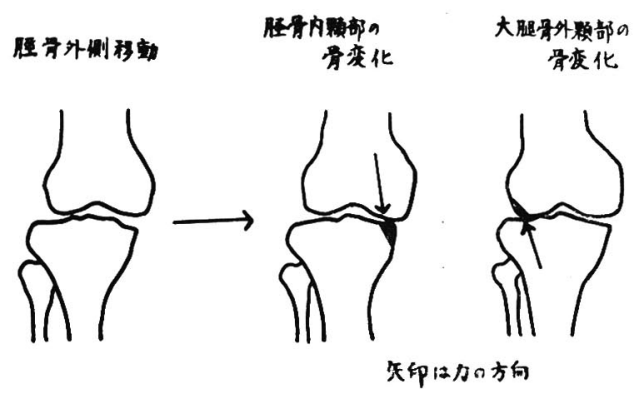

図 2 力学的作用想定図 


\begin{tabular}{|c|c|c|c|c|c|c|c|c|c|c|c|}
\hline$\stackrel{n}{\sim}$ & กิ & ot & 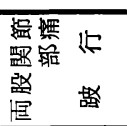 & 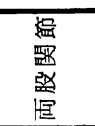 & 步 & ささ & † & I & I & 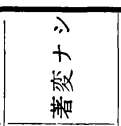 & 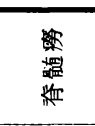 \\
\hline \pm & $\cong$ & $\leftrightarrow 0$ & 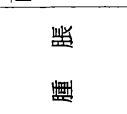 & 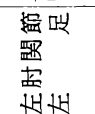 & 啸 & I & I & Ð & I & 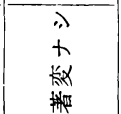 & 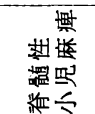 \\
\hline$\stackrel{m}{-1}$ & $\mathcal{M}$ & ot & 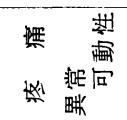 & 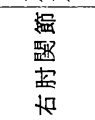 & I & In & $\omega$ & I & 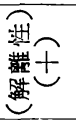 & 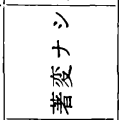 & 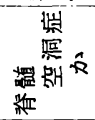 \\
\hline$\simeq$ & $\stackrel{\infty}{\infty}$ & ot & 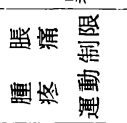 & 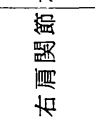 & 㭗 & I & I & I & † & 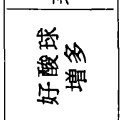 & 然 \\
\hline$=$ & ถิ & ot & 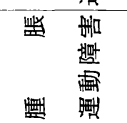 & 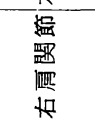 & $\sim$ & İ & I & I & さ & $\begin{array}{l}\lambda \\
+ \\
\text { 战 } \\
\text { 船 }\end{array}$ & $\infty$ \\
\hline 은 & గొ & 아 & 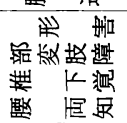 & 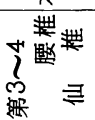 & $\omega$ & II & ‡ & I & Ð & 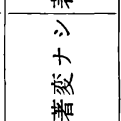 & \multirow[b]{11}{*}{ 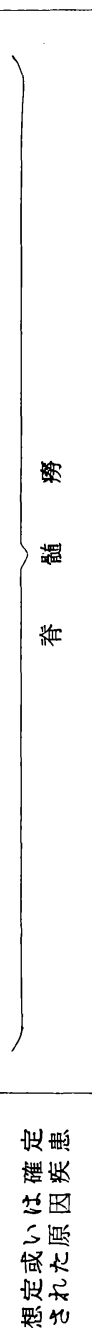 } \\
\hline$a$ & oิ & «o & 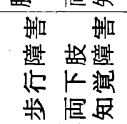 & 整 & 证 & ささ & 恝 & Ð & † & 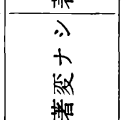 & \\
\hline$\infty$ & గొ & $\leftrightarrow 0$ & 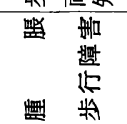 & 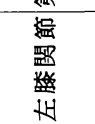 & 莱 & 至ささ & 䒠 & I & ‡ & 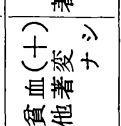 & \\
\hline$\sim$ & 8 & of & 监 & 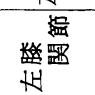 & III & †ャ‡ & ક & I & $\infty$ & 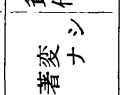 & \\
\hline 0 & $\overrightarrow{0}$ & ot & $\begin{array}{ll}\text { 紫 } \\
\text { 岿 }\end{array}$ & 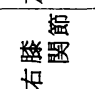 & III & ક๘ & ક & I & $\infty$ & 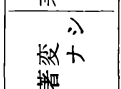 & \\
\hline is & 옹 & ot & 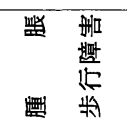 & 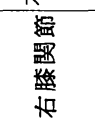 & $\omega$ & $a$ & ‡ & I & Ð & ar & \\
\hline$H$ & of & ot & $\begin{array}{ll}\text { 监 } \\
\text { 覀 }\end{array}$ & 簤 & III & I઼I & f & I & I & 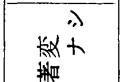 & \\
\hline$m$ & 饴 & $\leftrightarrow 0$ & 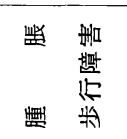 & 惿 & III & 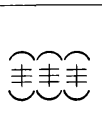 & 再 & I & I & 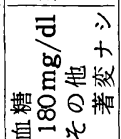 & \\
\hline$N$ & 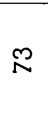 & ot & 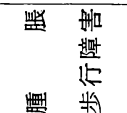 & $\begin{array}{l}\text { 智叫 } \\
\text { 回显 }\end{array}$ & a & ささた & 莑 & I & ‡ & 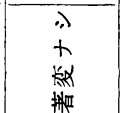 & \\
\hline- & 品 & Ło & 䱥些 & $\begin{array}{l}\text { H } \\
H\end{array}$ & 进 & 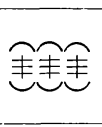 & 兲 & I & I & 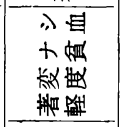 & \\
\hline $\begin{array}{l}\text { 露 } \\
\text { 装 }\end{array}$ & 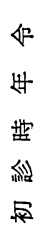 & 尿 & 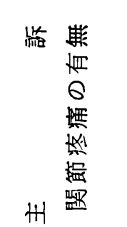 & 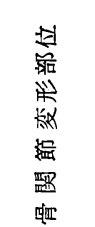 & 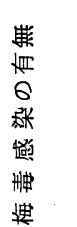 & 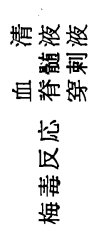 & 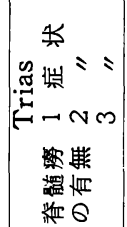 & 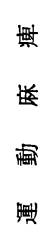 & 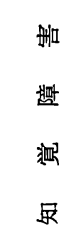 & 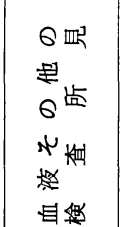 & \\
\hline
\end{tabular}


膜肥厚像を認めた。右は, 脛骨内顆部の軽度の骨破壊 と大腿骨外顆部の軽度の骨增殖を認め, また, 脛骨の 外側への移動，骨膜肥厚像を認めた。症例（4）では， 右側は, 脛骨内顆部の破壊之, 脛骨の内側への移動, 骨膜肥厚, 関節裂隙の狭小を認めた. 左は, 脛骨内顆 部の破壊, 骨膜肥厚, 脛骨の外側への移動を認めた. 症例 (5) では, 大腿骨内および外顆部の骨破壊, 脛 骨内扰よび外顆部の膨隆, 脛骨の外側への移動を認め た. 症例 (6) では, 脛骨内顆部の骨破壊, 脛骨外顆 部, 大腿骨内扰よび外顆部の膨隆, 脛骨の外側への移 動を認めた。症例（7）では，脛骨内顆部の骨破壊之 関節裂隙の狭小および脛骨の外倒移動を認めた。症例

（8）は，脛骨内顆部の破壊之脛骨の外側への移動を 認めた.

\section{考按}

我々の経験した症例中，年令分布，罹患関節，原因 疾患別などは，諸家の報告と大差なかつた．性別では， 諸家の報告では男性に多い様であるのに比して, 我々 の症例では，女性に多かつた．膝関節のX線所見によ る骨破壊および増殖の起り方に関しては，Turek が， 大腿骨内顆に初期に起るとのべているが，それらに関 する報告は少ない様である，我々が経験した膝関節の X線所見にて，共通に認められた事は，11関節，全例 に, 脛骨内顆縁部に骨破壊を主とする変化を認め, 大 腿骨に変化を認めたものでは，外顆縁部に著明にそれ を認めた事である．脛骨外顆部および大腿骨内顆部の みに高度の破壊をみたすのは，一例も認められなかつ た。 また，全例に，大腿骨および脛骨の骨膜肥厚像を 認め, 症例 (3) (7) (8) では, 比較的初期から骨膜 肥厚像を認めた。その他，ほとんど全例に，脛骨の外 側への移動を認めた. 特に比較的初期の症例 (3) で は，明瞭なる骨变化が起る前に，それを認め，その後 の経過で，脛骨内顆縁部に破壊を認めた．ちなみに， Turek, Imhäuser, Palma, Hollander らの紹介して いる著明なX線像を見ても，ほとんどが，脛骨内顆， 或いは，大腿骨外顆に，その変化が著明である。 ま た，それらは，ほとんどに，脛骨関節面の外側への移 動を認める. 以上の様な所見加，我々は，図 2 の ごとき力関係が膝関節に作用するすのと推察した．即 ち, 周囲軟部組織の弛䌅度の不均衡により, 大腿骨が 内側に亜脱臼する傾向を示し，体重負荷による力が， 抵抗の強い大腿骨関節面中央部加ら，より抵抗の弱い
脛骨内顆部に向かい，また，より抵抗の強い脛骨関節 中央部加 , 抵抗の弱い, 大腿骨外顆部に向う為, 脛 骨内顆部および，大腿骨外顆部飞初期の骨変化，お よび強度の骨変化を来たすすの之推察した.

神経病性関節症における 関節周囲支持組織 の 弛緩 に関しては, Otto RusseやSchinz らすのべている様 に, 筋肉の Hipotonia があげられている. Lanzによ れば, 膝関節に働く筋群の中で内側または外側に走行 をみるのは滕関節屈筋群で, 内側は主として, M. semimembranosus, M. semitendinosus, M. graciris caput tibiale gastrocunemii などであり, 外側は, M. biceps femoris, caput fibulare gastrocunemii などである. また，その力関係は，可能仕事能力で表 わすと，内側 2 筋で $30.0 \mathrm{mkg}$ で全体 (45.7) の 66\% を占め, 内側の方が相当強い様である. 以上の事から あ Hipotonia が平等に起つた場合, 関節の支持力が 失なわれながらも, 内側の支持力が外側のそれより強 く，内側に牽引されやすい事が推察される。それに加 えて, 歩行など体重負荷による衝撃により勒帯むひき のばされ, 動摇関節を生じ, 外側の支持力の方が弱く 脛骨の外側移動を生じ易いむのと思われる.

以上の様な理由から，我々は，著明な所見を呈する あのは, 誩断が容易であるが, 初期の診断として周囲 軟部組織の化骨, 骨增殖は勿論として, 骨膜肥厚像, 脛骨関節面の外側移動, 脛骨内顆縁抢よび大腿骨外顆 縁部の骨変化を, 注意深く観察することにしている.

\section{結語}

我々の経験した神経病性関節症に関しての概要を報 告すると共に, 膝関節の $X$ 線像について若干の検討を 加えてみた.

（稿を終るにあたり, 御助言, 御校閲戴いた恩師玉 井達二教授に深甚の謝意を表します.)

\section{文献}

1) Imhäuser : Hohmann's Handbuch d. Orthopädie, Ed. 1, 453, 1957.

2) Hollander : Arthritis, Ed. 6, 147, 1962.

3) Walter Mercer : Orthopedic Surgery, Ed. 5, 412, 1959.

4) De Palma : Disease of the Knee, 608, 1954.

5) Turek : Orthopedics, 200, 1959.

6) Otto Russe : An Atlas of Orthopedic Diseases. 368, 1964. 
7) Lanz: Plaktische Anatomie, Bd. 1, 261, 1938.

8) Schinz : Roentgen Diagnostics, Vol. II, 1401, 1952.

9) Aegerter-Kirkpatrick : Orthopedic Diseases, II nd Ed, 700, 1964.

10) Einhenholz : J. B. J. S., 44-A : 1485, 1962.

11) Donald, P. : J. B. J. S., 42-B : 1-4, 1960.

12) Cleveland : J. B. J. S., 41-A : 336, 1959.

13) Steindler: J. A. M. A., $96: 25,1931$.

14) Wiesemann : J. B. J. S., 38-A : 439, 1956.

15) 神中: 神中整形外科学. 270,291 , 昭 40 .

16）上村 - 他 : 整形外科. $2: 282$, 昭 26 。

17）城間：熊本医会誌。 $29: 728$, 昭30.

18）河路：整形外科. $8: 419$, 昭32,

19）柏木.他：外科. $19: 894$, 昭32.
20）吉野 - 他: 日整会誌. $32: 91$, 昭33.

21）宇賀：日整会誌. $32: 551$, 昭33.

22) 中野: 日整会誌. $36: 575$, 昭 37 .

23）蒲原 - 他 : 整形外科. $15: 11$, 昭39.

問 九大 塚本 行男

Steroid 注入によつて Charcot 関節様の変化を起 すという報告があるが，乙のような症例を経験されて いるか.

答 熊大 徳永 温正

ステロイド注入した症例に, 神経病性関節症が起つ た経験はない. 全て初期に Charcot joint と診断した 症例のみである.

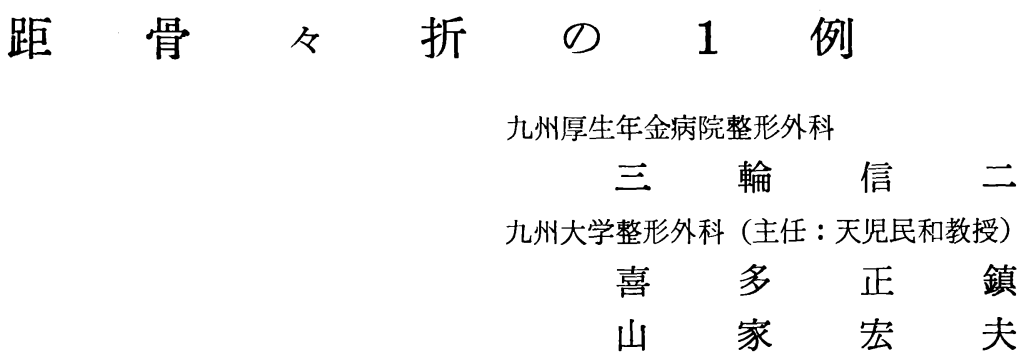

\section{A Case Report of Fracture of the Talus}

By

N. Miwa

Department of Orthopedic Surgery, Kyushu

Welfare Pension Hospital.

M. Kita \& H. Yamaga

Department of Orthopedic Surgery, Faculty of Medicine, Kyushu University.

There are many difficulties in the treatment of fractures and dislocations of the talus. We experienced to treat the fracture of the talus with posterior dislocation of the body.

We tried to reduce the rotated posterior fragment by Bobler's manoeuver without success. Then, reduction was performed by operation and two fragments were fixed with a Kirschner wire and a staple. In reducing the posterior fragment pushing the distal end of the posterior fragment backward was successful.

After twelve weeks immobilization in plaster cast, the talus has been protected by ishial weight-bearing apparatus below the hip joint.

At forteen months after the operation, the result is excellent.

距骨々折は比較的に稀ではあるが，距骨が全体重の かかる骨である関係上, 骨折自体は治㱂しても, 周囲
の骨との間に変形性関節症を起こし, 強い障害を生じ

て予後のよくない骨折である. 我々は後方骨片の転位 